\title{
Claiming and re-claiming the Ayeyarwady Delta, time and again: the case of Nyaungdone Island, Myanmar
}

\author{
Benoit Ivars ${ }^{1}$ \\ Jean-Philippe Venot \\ University of Cologne, Germany \\ Institut de Recherche pour le Développement (IRD), France
}

\begin{abstract}
Since 2011 and the transition to civilian government, Myanmar and the Ayeyarwady Delta in particular are witnessing swift and dramatic changes in the modalities of access and use of natural resources. Drawing from political ecology, and on the basis of ethnographic work conducted in Yeinek village tract in the Nyaungdone Township of the Ayeyarwady Delta, this article places recent resources dynamics in a historical perspective. Rather than seeing natural resources as a 'given', we see them as resulting from socially embedded strategies of resource-making. These strategies contribute to a constant redefinition of the "resource-frontier" the delta has historically been for multiple actors. Notably, we show how land for rice cultivation, and water for capture fisheries and aquaculture, have been made into key resources over time, often in an exclusionary way. Post2011 land and fishery reforms are the most recent examples of resource-making dynamics; they have certainly triggered significant resource re-allocation, but existing cross-scale patronage networks still largely shape how this takes place in practice. Finally, in this deltaic environment where resources are part water, part land, part rice, part fish, and the legitimacy of one's claims often hinges on proving prior use of a specific resource, it is the nature of the resource to be reallocated that is contested. In the newly politicized context of Myanmar, resources and institutional fluidity is in itself a frontier to navigate.
\end{abstract}

Keywords: Ayeyarwady Delta; Myanmar; fisheries; land; resource making; frontier; exclusion

\section{Résumé}

Depuis 2011 et la transition vers un gouvernement civil, le Myanmar et le delta de l'Ayeyarwady en particulier ont été les témoins de changements rapides et spectaculaires dans les modalités d'accès et d'utilisation des ressources naturelles. S'appuyant sur les cadres d'analyse de la political ecology et sur des travaux ethnographiques menés dans le village de Yeinek, au sein du Township de Nyaungdone dans le delta de l'Ayeyarwady, cet article replace la dynamique récente des ressources naturelles dans une perspective historique. Plutôt que de considérer que les ressources naturelles « existent » en tant que telles, nous considérons qu'elles sont façonnées au travers de stratégies et d'interactions sociales. Ces stratégies contribuent à une redéfinition constante de ce qui fait la « frontière » que le delta a historiquement été pour de multiples acteurs. Nous montrons notamment comment la terre - pour la culture du riz - et l'eau - pour la pêche de capture et l'aquaculture - ont été façonnées comme des ressources clés au fil du temps, et souvent en opposition l'une à l'autre. Les réformes foncières et des pêches initiées à partir de 2011 sont les exemples les plus récents de cette dynamique de production sociale de ressources. Elles ont certainement conduit à d'importantes réallocations de ressources, mais les relations de patronage existantes à différentes échelles déterminent encore largement la

\footnotetext{
${ }^{1}$ Benoit Ivars is a PhD candidate at the University of Cologne, Germany. Email: benoit.ivars "at" uni-koeln.de. Dr. JeanPhilippe Venot is Senior Researcher in the G-EAU joint research unit of the Institut de Recherche pour le Développement (IRD) and affiliated to the University of Montpellier, France and the Royal University of Agriculture (RUA) in Phnom Penh, Cambodia. We are grateful to the many people of Nyaungdone Island for their time and hospitality. We are also indebted to Ma Thet for her support during the fieldwork. We thank the editors and an anonymous reviewer for their comments. This work was supported by the German Research Foundation (DFG)'s Emmy Noether Program [Project Number 276392588] and the French National Research Agency (ANR) under the DOUBT project (http://deltasoutheastasiadoubt.com/).
} 
manière dont ces réaffectations se font dans la pratique. Enfin, dans cet environnement deltaïque où les ressources sont faites en partie d'eau, de terre, de riz, et de poissons, et où la légitimité des revendications dépend souvent de la capacité des acteurs à démontrer une utilisation antérieure d'une ressource spécifique, c'est la nature de la ressource à réaffecter qui est elle-même contestée. Dans le contexte politique actuel du Myanmar, c'est la fluidité de ces ressources et des cadres institutionnels qui constituent une frontière à naviguer en tant que telle.

Mots-clés : Delta de l'Ayeyarwady; Myanmar; pêche; terre; façonnage des ressources; frontière; exclusion

\section{Resumen}

Desde 2011 y la transición a gobiernos civiles, Myanmar y el delta del Ayeyarwady en particular están siendo testigos de cambios rápidos y dramáticos en las modalidades de acceso y uso de los recursos naturales. Basándose en la political ecology y en un trabajo etnográfico realizado en la zona de la aldea de Yeinek, en el municipio de Nyaungdone, en el delta del Ayeyarwady, este documento sitúa la dinámica reciente de los recursos en una perspectiva histórica. En lugar de ver los recursos naturales como algo "dado", vemos que lo último es el resultado de estrategias socialmente arraigadas de creación de recursos. Estas estrategias contribuyen a una constante redefinición de la "frontera de los recursos" que el delta históricamente ha sido para múltiples actores. En particular, mostramos cómo la tierra -para el cultivo del arroz- y el agua -para la pesca de captura y la acuicultura- se han convertido en recursos clave a lo largo del tiempo, a menudo de forma excluyente. Las reformas agrarias y pesqueras posteriores a 2011 son los ejemplos más recientes de la dinámica de creación de recursos; sin duda han desencadenado una importante reasignación de recursos, pero las relaciones de patronaje de escala cruzada existentes todavía determinan en gran medida la forma en que estas reasignaciones se llevan a cabo en la práctica. Por último, en este entorno deltaico en el que los recursos son parte agua, parte tierra, parte arroz, parte pescado, y la legitimidad de las reivindicaciones de cada uno depende a menudo de demostrar el uso previo de un recurso específico, es la naturaleza del recurso que se va a reasignar lo que se cuestiona en sí misma. En el contexto recientemente politizado de Myanmar, los recursos y la fluidez institucional son en sí mismos una frontera por la que hay que navegar.

Palabras Clave: Delta del Ayeyarwady; Myanmar; pesca; tierra; creación de recursos; frontera; exclusión

\section{Introduction}

The Ayeyarwady Delta ${ }^{2}$ in Myanmar has long been seen as a "resource-frontier" to be reclaimed. This came to the fore in 1852, with the annexing of Lower Burma by the British. From that point onwards, rice and the land upon which it was grown were socially constructed as resources, and, in the 1930s, the delta eventually became one of the largest rice exporting regions in the world (Adas 1974; van Schendel 1991). In this article, we seek to demonstrate that the delta is not only a "rice-frontier" to be conquered. Rather, we argue that multiple resource frontiers are overlapping, one of which being the uncertain and ever-shifting institutional framework and political configurations that govern access to and use of resources. The capacity some actors have to define what "makes" the resources (capture fishery, rice, fishponds) in a delta environment and to navigate ever shifting political configuration is a resource in itself - one that makes the delta landscapes.

In the British colonial period (1852-1948), the making of the delta as a "rice frontier" was underpinned by the notion of "waste land", that is, land that was considered as "underutilized", and hence could be allocated for reclamation. This notion of wasteland and the focus on a "rice-frontier" continued to underpin post-colonial laws as illustrated by the Wasteland Instructions (1991) that clarified the criteria to identify and allocate "underutilized" land and the obligations attached to their reclamation. As Ferguson (2014) argues, however, qualifications such as "waste", "unused", "vacant", or "underutilized" have less to do with the land itself than with prevailing political and economic power relationships. In the 1990s and 2000s, when Myanmar was ruled by military regimes ${ }^{3}$, these notions have for instance allowed and legitimized large-scale land reclamation and

\footnotetext{
${ }^{2}$ We use the official name of the delta/river (Ayeyarwady) and of the country (Myanmar) without political connotations.

${ }^{3}$ The country has been ruled by three successive military regimes since 1962: the Revolutionary Council (1962-1974), transformed into the Burma Socialist Programme Party or BSPP (1974-1988), the State Law and Order Restoration Council or SLORC (1988-1997), and the State Peace and Development Council or SPDC (1997-2011).
} 
dispossession (Hudson-Rodds and Sein Htay 2008; San Thein et al. 2017, 2018; South and Katsabanis 2007), notably in the deep water areas of the delta that supported capture fisheries.

With the transition to civilian governments in 2011 and subsequent far reaching land and fisheries reforms, long-dormant resource conflicts linked to these dynamics of reclamation and dispossession have emerged (Mark 2017; Mark and Belton 2020; Salai Thant Zin 2019a, 2019b). In the hybrid environment of the Ayeyarwady Delta, where land and water are co-constitutive of each other, however, conflicts are not only about claims and counterclaims to access resources. As resources themselves (part land, part water, part rice, part fish), and modalities of access and uses, are continuously shifting and multiple regimes of justification coexist and can be used to legitimatize certain claims over others, what "makes the resources" is actually uncertain, and this matters. Beyond multiple claims, what is at stake are multiple resource-making strategies confronting each other.

Our analysis is inspired by scholars from critical environmental geography and political ecology who have advanced a relational understanding of natural resources and argued that the latter are "made" through historical socio-political relationships as opposed to "being" per se (e.g. Barney 2009; Peluso 2012). Central to our analysis is the recognition that contemporary resource dynamics need to be understood historically, and result from past resource-making strategies. This leads us to question the idea of the delta as a "rice frontier" (Adas 1974) progressively conquered and ultimately "closed" as land was reclaimed. Rather, we focus on analyzing the strategies through which multiple frontiers -as social and political phenomena- are drawn and continuously re-made. We argue this happens on the basis of different enactments of the resources of the delta and their potentialities, and how these have changed and may change in the future. We hence move away from the land bias that characterizes current reforms and scholarship. This is needed to reflect the hybrid character of our case study area, the Yeinek village tract of Nyaungdone Township ${ }^{4}$, which remains flooded part of the year, has long supported capture fisheries, witnessed large-scale land reclamation, and more recently, aquaculture development.

In the following section, we further develop our analytical framework and discuss the concepts that underpin our analysis, resource-frontier and resource-making. Drawing from ethnographic research by the first author who spent more than 12 months living in the Nyaungdone Township between 2017 and 2019, and archival work, we then provide a historical account of the making of the Nyaungdone Island (Section 3). In Section 4, we turn towards analyzing resource-making strategies characterizing recent land and fishery reforms. A short section concludes, highlighting that (1) contemporary struggles incorporate and perpetuate a history of resource-making aimed at reorganizing and redirecting the delta resources to locally grounded and cross-scale patronage networks, and (2) there is significant uncertainty and disputes occur regarding the nature of the resources themselves in a multi-folded institutional framework, which constitutes a frontier in its own right that actors need to navigate if they want to legitimize their claims over others.

\section{A relational understanding of the Ayeyarwady Delta's resources}

Relational and assemblage thinking has a growing influence across critical political ecology (Bakker and Bridge 2006; Barney 2009; Bridge 2009; Peluso 2012) and anthropology (Li 2014a; Richardson and Weszkalnys 2014; Tsing 2011). One of the central tenets of such approach is the "unnaturalness" of natural resources. Far from being inert 'things' that await discovery and use, natural resources are enacted through complex historical processes influenced by cultural, economic, technological and political factors. Resources do not exist per se but are being continuously produced and reproduced. Such understanding carries a sense of resources complexity that speaks to their heterogeneity and provisional character made up from the gathering or assembling of various elements and relations. Engaging with what she calls the "global land rush", Tania Murray Li (2014a) posits for instance that the "making of land" as a resource accessible for global investment occurs not only through discourses, but also through symbolic and material inscription devices (such as land

\footnotetext{
${ }^{4}$ The Myanmar administrative structure consists of village-tracts, townships, districts, states/regions and the union/central level. A village tract is made up of several village settlements.

The names of places and actors/organizations within the Nyaungdone Township have been anonymized.
} 
titles, maps, trees, etc.). In this perspective, resource-making is "constitutive and constituted within arrangements of substances, technologies, discourses and the practices deployed by different kind of actors" (Richardson and Weszkalnys 2014: 16), and hence it is political.

More recently, relational and assemblage analytics have been used in relation to the concept of "resource frontiers" (Barney 2009; Cons and Eilenberg 2019; Rasmussen and Lund 2018; Watts 2012). Originally associated with the advance of colonial settlement in North America, the "frontier" has been conceived as an area of emptiness in both physical and ideological terms, a new "open space" to be conquered (Turner 1920: 212-214). The concept of the frontier has since been widely criticized and reworked in ways that are more attentive to the social practices through which the frontier is "made" (in very much the same way that resources are made; e.g. Barney 2009; Peluso 2018). Michael Watts (2018) provides an account of frontiers as "spaces formed before the arrival of law and order (and systems of authority)" or "after legal and authority systems collapse or wither." He uses the term "frontier-space" and argues that, in these, the definition of the forms of authority and power legitimacies remain contested. The uncertainty or insecurity that emerges in relation to shifting state capabilities and forms of rules can produce and reproduce frontier-like spaces. Echoing this understanding of frontiers as social formations, Rasmussen and Lund (2018) depict frontiers as something that happens in and to space, but is not space itself (see also Kopytoff 1987). They describe frontiers as formed by shifting policies, property regimes, political orders and legitimacies. The "making of frontiers" notably leads to reshaping the modes of resource access and control, or, in other words, to "making resources." The frontier as a social formation hence consists of the ambiguous interface between legal and illegal modes of access to resources, between previous and new forms of property and use rights, between multiple legitimacy registers, between new and old -but never fully vanishing- social or political order.

Frontiers are then characterized by a sense of uncertainty but also by attempts of "the State" (or any power-to-be) to assert control over, and shape them in specific ways in what constitute practices of territorialization (e.g. Peluso and Vandergeest 2011; Woods 2011). However, as highlighted above, frontiers are never really empty (they are "made" empty through specific resource-making strategies) and frontiermaking strategies such as practices of territorialization can lead to destabilization, rupture and possibly violence towards the social groups and individuals inhabiting these spaces. For those able to adjust and change practices, frontier and resource making may offer new opportunities for expanding access and control over resources, hence offering a potential for surplus production and appropriation (Ribot and Peluso 2003). For others who may struggle to make sense of these uncertain dynamics, they may, on the other hand, constitute a new set of risks and vulnerabilities and result in new forms of economic enclosures, marginalization and dispossession (Li 2014b). To sum up, "frontier making", that is, the making of specific spaces through the identification and production of resources and related modes of access and use, opens new horizons (Peluso and Lund 2011). Here, the uneven abilities of different actors to adapt to the changing political and environmental contexts is critical to understanding how the frontier unfolds in practice.

We argue that adopting such a perspective can shed new light on resources dynamics and disputes currently at play in the Ayeyarwady Delta of Myanmar, for several reasons. First, the delta has historically been framed as a rice frontier in the classic sense of the term, e.g. an empty space to be conquered by the state on the ground that delta-land had a high potential but was underutilized. The relational and assemblage analytics allow for interrogating the politics of shaping the delta as such a frontier, and the related dynamics of accumulation and dispossession that stemmed from it. Second, doing so in the current political context of Myanmar, which is going through an incomplete and fragile transition from authoritarianism towards more democratic representation, is interesting at another level. It allows engaging with what the assemblage analytics highlights as constituting a frontier too, e.g. the uncertainty that relates to shifting power regimes and legitimacy frameworks and the (in)ability of different actors to navigate it and reshape access and use to resources. Finally, the notion of uncertainty acquires yet another dimension in a hybrid/amphibious environment such as the Ayeyarwady Delta. Though generally seen through the prism of land, deltas are particularly prone to multiple resource-making strategies (on the basis of which frontiers can be drawn and re-drawn in an ever-shifting terrain), and to acts of resistance towards attempts of extraction and resource control, as shown by David Biggs (2011) in the case of the Vietnamese Mekong Delta. His "quagmire" metaphor echoes both the physical space 
of the delta and the political entanglements associated with it. We draw from this work to interrogate the strategies and social practices through which the Ayeyarwady Delta resources (and conflicts) have been and continue to be produced and reproduced (which we call resource-making), and how these define an ever-shifting frontier, which has both a "ground reality" but also needs to be understood as a political formation.

\section{Resource-making on the Nyaungdone Island: an historical perspective}

Waste land, horseshoes and capture fisheries in the shadows (1852-1948)

The Nyaungdone (Yandoon) Island lies within the Nyaungdone and Maubin Townships and is limited by the Ayeyarwady River on its north-western side and by the Pan Hlaing River on the north-eastern side (Figure 1). It has a saucer-like shape, characteristic of the main deltaic islands, with land gently sloping from the riverbanks towards the "center" where creeks and wetlands drain southwards (Maxwell 1910).

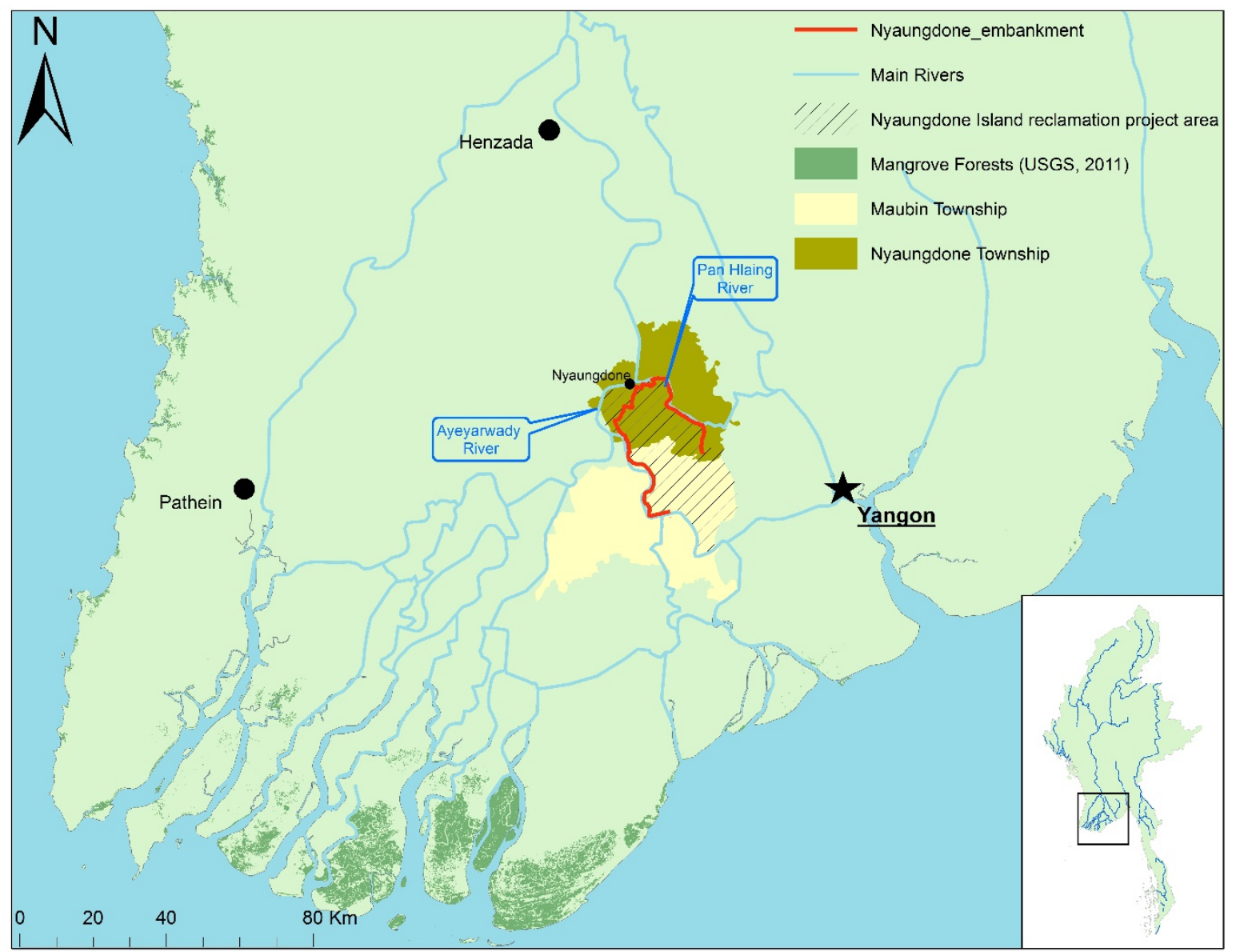

Figure 1: Location of the study site. (source: the authors)

After the annexation of the delta region by the British in 1852, the colonial administration regarded the island (and the delta in general) as a mix of jungle, grassland, and swamps. The area was considered as a "wasteland" holding some potential for agricultural development (Barnett 1913). In Nyaungdone, the first large scale attempt at land reclamation took place in the early $20^{\text {th }}$ century and consisted in the construction of a socalled "horseshoe embankment" due to its shape along the northern riverbanks (Volker 1964). The embankment 
was left open in the South, hence affording only partial protection from floods but still containing these and allowing for evacuating rainfall through the natural drainage system. The horseshoe embankment materialized the new land frontier, "encouraging immigration and showing what could be done in areas previously looked on as unculturable swamp" (England 1939: 141). The embanking of the Nyaungdone Island raised considerable debate, however, among British administrators (GoBB 1923).

The debate was grounded in different views regarding the nature of Nyaungdone Island's resources. A particular concern was the presence of productive inland capture fisheries, known as Inn. These were a significant source of revenue for the colonial administration since the 1875 Fishery Act and Rules. Under British rule, Inn fisheries were leased through a system of annual auctions by which exclusive usufruct rights (from September to April) were sold to the highest bidder. They belonged to the rural elite locally called in'thu-kyi' (Khin 1948; Reeves et al. 1999). Small-scale fishermen, locally known as yei-paw-yei-hlyan (floodplain fishermen) could still access these fishing grounds but, between September and April, had to negotiate access with the right holders and/or work for them as laborers. They also used the flooded land in the vicinity of the Inn fisheries as fishing grounds, sometimes leading to conflicts with farmers.

The potential tensions between cultivators and fishermen and between two resource-making strategies had been identified early on (e.g. Smeaton 1882; Tin Gyi 1927). As described by Khin (1948: 38), the principle underlying Inn fisheries consists in "cutting off the escape of fish out of the flooded depression or down the outlet creeks by setting up screens across their way of escape and then catching the fish thus shut in." By installing fishing gears along rivulets and drainage channels, fishermen were said to deteriorate the drainage network that was crucial to shorten inundation time and reclaiming low-lying lands (PWD 1927).

Despite some government officials considering that capture fisheries should be given precedence in areas such as Nyaungdone, the vision that dominated the first part of the $20^{\text {th }}$ century was that fisheries were detrimental to the 'drainage of the country', the extension of rice cultivation and related increase in government revenue (increase in land revenues more than compensating fishery-related revenues). This priority given to rice cultivation (and land) vis-à-vis other potential resources clearly transpired since undrained land supporting Inn fisheries in the interior of Nyaungdone Island such as the Yeinek village tract was eventually classified as "waste remaining open to reclamation" (GoBB 1923).

\section{Secured land, unruly waters and fisheries (1948-1988)}

After the independence of the country in 1948, the Ayeyarwady Delta was not only a vanishing rice frontier due to the deterioration of infrastructure and large scale abandonment of land (van Schendel 1991: 211) but an area of contestation of state authority by anti-government groups such as the Communist Party of Burma (CPB) and the Karen National Union Party (KNUP) (Aung Zaw 2008; Smith 1999).

Known as the country's rice basket, the delta - and notably its deep water areas- became the "stomach" of the rebellion (Maung Aung Myoe 1999: 136). The government exerted strong control over agricultural village tracts notably through its forced paddy procurement policy (1964-2003, Thawnghmung 2003, 2004). Fishery-oriented villages, on the other hand, featured as "unstable" areas in the eyes of the state (e.g. Htwe Myint 1990) and, according to our interlocutors, Inn fisheries constituted the largest source of revenue for both the KNUP and CPB in the Maubin District in the 1950s and 1960s. In Yeinek, anti-government groups roamed the deep water areas that supported Inn fisheries, and because these were difficult to access (flooded vegetation, swamps, and dense networks of rivulets still dominated the landscape), it was not easy for government authorities to find out what exactly was happening there. For many years, rebel groups exerted a de facto control over Inn fisheries and instructed villagers to form groups (tha-ma-ga) that were meant to manage the fisheries collectively. Although fishermen continued to auction fisheries at the government office, it was particularly risky to do so without previous endorsement by rebel leaders. The leaders of each tha-ma-ga, who were also the leaseholders (in'thu-kyi') from a government point of view, then, had to pay the value of the auction twice: to insurgents and to the government.

In 1969, the government army drew up a plan known as the Four-Cuts (hpyat lei' hpyat) to retake control over the country and the delta in particular (Maung Aung Myoe 1999). A metaphor, illustrative of the fact that 
fishery and water resources (as opposed to land and rice) were associated to anti-government groups, was used to describe the objective of the plan: it aimed at draining the water (the tax base and connections of insurgent groups) so that the fish (the insurgents) could not swim (operate). In Yeinek, military posts were established at the entrance of the main streams and movements strictly controlled. The rebel groups could not operate in the area anymore and fled from the delta region. The Nyaungdone area was declared "white" (i.e. under government control) in the early 1970s and the government implemented its policies under the "Burmese Way to Socialism" (Information Department 1962). This notably involved the promotion of rice cultivation in a context where land had been nationalized since 1948 and with collective management of inland capture fisheries.

In Yeinek, almost all Inn fisheries were put under the management of fish production cooperative groups formed in 1972 in accordance with the 1970 Cooperative Act. Fisheries were allotted by the government to adjacent villages. ${ }^{5}$ Depending on the area, a group could operate one or several Inn fisheries. Although the government lent money to these groups at low interest rates, these were short-term loans and the cooperatives depended on funding from rich fishermen in the village who had capital, owned fishing gears and boats, were often involved in trading fish (and might even be former Inn leaseholders). Although these wealthier villagers involved in fish trading were formally excluded from producers' cooperative groups, they managed to retain control over fishery resources by building on pre-existing patron-client relationships that were based on indebtedness. As stated by a former cooperative committee member, "the members worked with their respective traders, and just like before, traders covered the expenses for the members who worked the fishery and in return they sold fish only to "their" traders" (interview data). At village level, the leaders of each cooperative, selected among the members, generally worked on the main portion of a fishery (chaung ma) using hired wage laborers and letting other cooperative members work on the minor streams (lek-tek) and pools (aing). In some cases, traders could "place" their clients (individuals or groups of small-scale fishermen) in the most productive areas by colluding with the cooperative leaders who de facto "sold" access to them. Thus, subleasing and redistribution of fisheries were still practiced, although they were risky, during the socialist period. In Yeinek, a case of selling and subleasing led the members of the village tract level cooperative to being imprisoned as the arrangement was denounced by other villagers.

\section{Draining and controlling it all: paddy land and fish ponds (1988-2011)}

Despite bringing the delta under their control, in the 1970s, central authorities became increasingly concerned about declining rice surplus, most of which had historically come from the region. In this context, Nyaungdone Island was identified as a potential area for further land reclamation as part of the Lower Burma Paddyland projects (World Bank 1976, 1978) and was described as "the area likely to offer the highest returns on investments to increase paddy production in the delta" (Sir William Halcrow \& Partners 1982: 542). Nyaungdone Island, however, was not included under the Paddyland projects due to the potential losses of fisheries, wildlife habitats, and changes in the hydrological regime of the creeks that land reclamation was expected to cause. The project was not abandoned however and, in the 1980s, the Island was identified once more for reclamation by the Ministry of Forest and Agriculture. The latter further stressed the large extent of "unused" and "waste" land of the Island in a report dated 1988 (Htwe Myint 1990; Irrigation Department 1988).

Large stretches of low-lying wetlands that were said to "have been legged behind in agriculture [sic]" (The New Light of Myanmar 2001) constituted an opportunity for the government to further exert its control over the area by land allocation, if such land could be drained. This eventually happened as part of the Nyaungdone Island Reclamation Project (1994-2000; see Figure 2) that contributed to the broader Tapping the Under-Water Treasures ${ }^{6}$ plan initiated in 1991-1992 (as far as the Maubin District is concerned). The project was aligned with state-building objectives, which were to be achieved through (1) the construction of roads and bridges so as to reincorporate these difficult to access deep water areas into the state domain (The New Light

\footnotetext{
${ }^{5}$ Under the Burma Socialist Programme Party (BSPP) government (1974-1988), most Inn fisheries were managed by villagers organized in cooperatives or directly by the state (through the People's Pearl and Fishery Corporation). Some fisheries remained in operation on a private basis, however.

${ }^{6}$ The 'treasure' represents the potential (agricultural) land that partly remained under water.
} 
of Myanmar 2003b), and (2) land reclamation and its subsequent allocation on the ground if it had been "underutilized" until then (MoAI 2002). Large tracts of deep water areas in Nyaungdone Island were legally categorized as wasteland (or Vacant, Fallow or Virgin Land (VFVL)). ${ }^{7}$ According to the Wasteland Instructions dated 1991, this meant such land could and would be allocated to private entities (including with foreign capital) regardless of any potential prior uses and even if these areas covered Inn fisheries and/or had been cultivated by smallholder farmers. This happened concomitantly with the enactment of the Freshwater Fisheries Law of 1991 that reestablished the principles of competitive bidding to access Inn fisheries.

Such concomitant shifts in the land and fishery legal frameworks underpinned complex dynamics of resource-making and redistribution. In Yeinek, a village tract mostly orientated towards capture fisheries until then, this dual uncertainty (over the type of resource -land versus fish- and over who could lay claim on it) largely "worked" at the expense of small-scale fishermen. First, the categorization of large tracts of land as VFVL and their subsequent allocation put pressure on the fishery sector as land concessions sometimes encroached on Inn fisheries areas. This made it more common for Inn leaseholders to lay claim on the flooded area adjacent to their Inn (something they had traditionally done). This de facto limited the scope for smallscale fishermen to access these areas as they used to by paying unofficial "entry fees" to the nearby Inn leaseholder. Second, access to Inn fisheries delineated as such was highly disputed. Following the Freshwater Fisheries law of 1991, competition for access and control of Inn fisheries increased since the highest bidder at auction (not necessarily resident of the village tract) was granted a yearly or long-term lease, as had been the case under British rule. In Yeinek, and even though there was intense strife over access to Inn fisheries within the village tract, some well-off fishermen got together to keep neighboring fisheries under the management of village residents. They agreed among themselves who would auction (in the name of several fishermen) and later attributed different areas of the Inn to independent fishermen or groups, depending on their respective contribution to the auction price.

VFVL to be reclaimed was granted on a 30-year lease basis, free of charge, under the condition that the land be reclaimed and put under cultivation within three years (e.g. Warr 2000). This was aligned with the government's nation-wide ambition that private entrepreneurs, considered as "colleagues who came to cooperate with the government" (The New Light of Myanmar 1999), would reclaim large tracts of land. In the Maubin District, over 40,468 hectares of VFVL were allocated to 271 companies (e.g. the highest concentration of land concessions observed in the Ayeyarwady Region in the 1990s and 2000s). In the northern part of the Nyaungdone Island the main private entity that benefited from VFVL concession was the Treasure Land Company (TLC). In 1997/1998, TLC received 14,000 out of the 25,000 hectares that had been classified as VFVL under the Nyaungdone Island Reclamation Project. However, land reclamation and rice cultivation by TLC did not take off. Several reasons were advanced by our interlocutors, among which the difficulty to find the labor force needed to reclaim and cultivate such a large area. According to former officials involved in the Nyaungdone Island Reclamation project, in 1999/2000, the area developed by the company was only about 800 ha. Our interviews also highlight that the main reason why land development did not take place is related to the fact that TLC had no special interest in agricultural development. Its presence in Nyaungdone was largely motivated by the possibility that it offered to strengthen ties with the military regime and develop other businesses elsewhere. The slow progress of land reclamation in the 1990s in Nyaungdone Island was not only linked to the politics of land allocation to TLC. Local inhabitants also benefited from land allocation, but few had the necessary capital and willingness to reclaim it. Indeed, paddy yields were low and uncertain due to persisting irrigation and drainage difficulties despite the construction of new water infrastructure, and uncontrollable rodent attacks. Only well-off residents engaged in rice cultivation in the vicinity of village settlements. Due to slow progress in land reclamation, further land reallocation took place from the late 1990s to the mid-2000s. Reallocations were a way for the military regime to extend social control and largely benefitted private entrepreneurs, companies, military units, administrative departments and village headmen.

\footnotetext{
${ }^{7}$ The Township level SLORC/SPDC had the authority to identify and designate wasteland or VFVL (Thawnghmung 2003).
} 


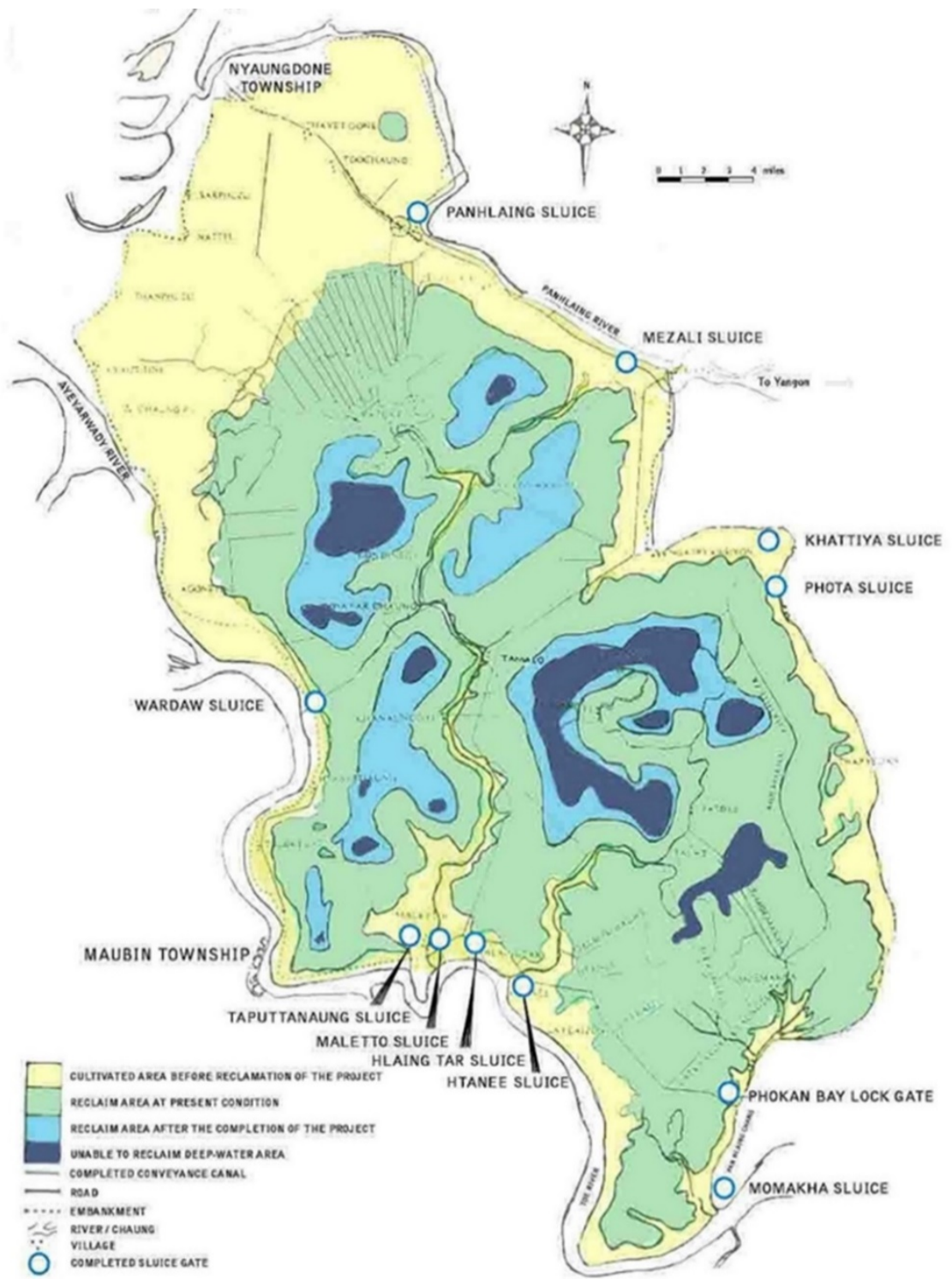

Figure 2: The Nyaungdone Island (as of 1994) reclamation project (1994-2000). (adapted from MoAI 2002)

Not only was land allocated to companies and outsiders but so were Inn fisheries, now posing serious threats to the village elites that saw their chief tools for surplus extraction undermined. Concessionaries were in most cases given long-term leases over Inn fisheries (kyei"taing; 3 to 9 years in Nyaungdone) located in the vicinity of their land concession, thereby depriving local fishermen from direct access to fishing grounds. Quite often, concessionaries actually sub-let the Inn fisheries to local fishermen and generated significant surplus. Their involvement in the sector created an extra layer of rent-capture within a system that was already vertically structured (see Section 3). Similar to Campbell's analysis (2019), the SLORC/SPDC was a period of increased inequalities leading to growing marginalization. On the one hand, the construction of infrastructures for irrigation and drainage (sluice gates) and for aquaculture (fish ponds) led shrinking capture fishing grounds and disrupting fish migration routes. On the other hand, powerful villagers who had better financial conditions and political connections were able to monopolize access to the best (available) fishing grounds without restriction, 
by collaborating with official concessionaries. Small-scale fishermen (the yei-paw-yei-hlyan or floodplain fishermen) who depended on flooded area targeted for reclamation were particularly affected and many migrated to urban peripheries or other fishery areas where former patron-client relationships that existed in Yeinek have been re-established.

The involvement of concessionaries in the fishery sector also led to reshaping the resource itself as fish ponds progressively replaced open water areas and Inn fisheries (see Figure 3). Indeed, at the time, the official policy of the Ministry of Livestock and Fisheries was "to provide assistance to those who upgrade the natural lakes into fish ponds as much as possible" (The New Light of Myanmar 2003a). ${ }^{8}$ Further, against the backdrop that the TLC's apparent failure provided, government authorities considered that whenever it proved "impossible" to cultivate rice, agricultural land could also be turned into fish ponds; this required the issue of an official document known as $\mathrm{La} \mathrm{Na}$ (section) 39 under the Land Nationalization Act of $1953 .^{9}$

The same system of economic patronage that characterized access to Inn fisheries and land shaped the access to fish ponds. As most concessionaries did not have the labor force to extract surplus from these ponds, they rented them out unofficially to locally powerful individuals who assumed the difficult task of exploiting and securing them, but still making significant benefits. Overall, for concessionaries, fish ponds proved a more effective mode of resource control and rent extraction from the VFVL or Inn fisheries they had been granted. The fact that land left "unused" after three years could be withdrawn by the state and redistributed had indeed offered an opportunity for local villagers and fishermen to claim access and to use some portions of these vast tracts of open water and land allocated to concessionaries. With the construction of fish ponds, the situation changed. It became more difficult to argue that land was unused as natural streams (and fish) were quite often redirected into fish ponds. Being hired to build then work in the fish ponds and adjacent fisheries that had been granted to concessionaries, villagers contributed to shaping their own exclusion as they lost their open access to these areas where they previously fished.

To sum up, in the 1990s and 2000s, the military government developed an economic patronage network through which the deltas land and fishing resources were "made." It fostered a symbiotic relationship with selected private companies, granting them concessions in exchange for economic and political support. In turn, these concessionaires developed relationships with village elites who then had privileged access to the concessionaire's resources, including land excavators, fuel, fish feed and investment capital.

\section{Today, what makes the resource in a highly politicized landscape (2011-)?}

"When the Inn (lakes) disappear, fish ponds appear" (authors' translation). Extract from a Facebook message by a Member of Parliament affiliated with the NLD (National League for Democracy) Party, Maubin District, accessed on 10/10/2019

This message echoes the frustration of NLD representatives regarding the hardship faced by local farmers and small-scale fishermen in Nyaungdone, though it is also imbued by politics. ${ }^{10}$ Their frustration

\footnotetext{
${ }^{8}$ The excavation of ponds had already been promoted in the early 1990s by the SLORC as part of the 'One Hundred Pond One Hundred Farm' initiative that aimed at developing fish-rice integrated production systems. The 1989 Aquaculture Law allowed the construction of ponds on uncultivated 'wasteland' and legally recognized ponds that had been constructed previously.

${ }^{9}$ Restrictions to convert agricultural land into fish ponds have been progressively relaxed since 1991 as the government established high aquaculture production targets. However, fish pond development is constrained by the Farmland Law (2012) and the Vacant, Fallow and Virgin Land Law of 2012 (amended in 2018). Converting agricultural land into fishponds requires obtaining a formal authorization; this is a complex and lengthy process with steps at different administrative levels under the General Administration Department (GAD) and the payment of substantial unofficial fees (Belton et al. 2015).

10 The first 'post-junta' (SLORC/SPDC) national and region/state elections took place in 2010 and saw a massive win for the Union Solidarity and Development Party (USDP), Myanmar's largest military-backed party. In the 2015 general election, the USDP and other political parties that had competed in the 2010 elections lost completely to the benefit of other parties and notably the NLD party, as observed in Nyaungdone constituency.
} 
notably relates to practices of some Village Tract Administrators (VTAs), often affiliated to the Union Solidarity and Development Party (USDP), who have successfully managed to retain their influential position for decades and currently collaborate with private entities to excavate fish ponds, sometimes illegally (Belton et al. 2015; on aquaculture see also Filipski and Belton 2018). Under the SLORC/SPDC regimes, VTAs who are the lowest-level administrators, also acted as intermediaries between the military government and concessionaries and as such they managed to secure access to significant land areas or Inn fisheries during that era. They acted, and still act, as patrons of clientelist networks by redistributing usufruct rights to the resources they secured, also controlling a large share of the village economy, notably through money lending. Our interviewees do not necessarily perceive the fact that their VTAs became "quasi land and water lords" negatively, if they redistribute part of their benefits to the residents of the community. Indeed, the local economy still depends on close relationships between villagers and government officials, and an influential patron/VTA can drain more benefits to the village in addition to "buffering" any government action perceived negatively. NLD politicians, however, face a conundrum: on the one hand, they seek to unknit such practices and the clientelist networks inherited from the military regime to convince villagers that their candidate to the VTA election represents an alternative; on the other hand, they often rely on these existing networks and on the VTAs affiliated to competing parties to push through their rural development policy, and may even directly benefit from these networks. In the following sub-sections, we describe resource-making dynamics at play in this newly politicized context through two case studies: (1) a case whereby local fishermen tried to regain access to Inn fisheries that had been encroached by fish ponds built by a private company and (2) a case where local residents claimed access to land that had been allocated and redistributed several times.

\section{Re-claiming Inn fisheries}

Since the transition to civilian governments in 2011, resources reallocation in the Ayeyarwady Region (which covers most of the delta area) has been high on the political agenda. With the enactment of the 2012 Ayeyarwady Region Freshwater Fishery Law (later replaced with a similar law in 2018; Tezzo et al. 2018), the government of the Ayeyarwady Region recognized the rights of floodplain fishermen and laid the ground for the reallocation of Inn fisheries to groups of small-scale fishermen and "Inn-less" villagers (a term that echoes the word "landless" and the "land to the landless" moto that characterizes recent land re-distribution schemes, see Section 4). ${ }^{11}$

Inn fisheries constitute a considerable political resource for the NLD-led government in a context where $86 \%$ of the leases were benefiting individual entrepreneurs and concessionaries, two thirds of whom did not belong to the community located in the vicinity of the Inn fishery they exploited (Tezzo et al. 2016). The regional government hence instructed local officials to priorize the granting of exploitation rights for Inn fisheries auctioned under a certain price, to small-scale fishermen constituted in groups. ${ }^{12}$ Such allocation priority given to small-scale fishermen groups further extended to (1) Inn fisheries encroached by fish ponds, and hence potentially conflictual; and (2) cases where farmers and fishermen were willing to find solutions in case of conflicts over boundaries (Hein Ko Soe 2018; Yin Nyein et al. 2018). It also came together with an attempt to clarify who was liable to pay the Inn auction price. ${ }^{13}$ Although made legally possible in 2012, allocation of Inn fisheries to groups was only implemented by the DoF from 2016/2017 (Campbell 2019). In

\footnotetext{
${ }^{11}$ Fishery management and revenue assessment was decentralized to regional governments in 2008.

${ }^{12}$ Auctions usually take place at the District Department of Fisheries (DoF) office. The bidding process is handled by two committees. The first committee is responsible for awarding the lease and chaired by the District DoF director with the Township DoF directors being committee members. The second is in charge of monitoring the bidding procedures, with the regional DoF official being the chairman of the committee and Members of Parliament (MPs) being its members.

${ }^{13}$ When an Inn fishery is encroached by fish ponds, the DoF identifies the Inn area that remains 'open' and the area that has been converted into fish ponds. In theory, the Inn leaseholder is liable to paying only part of the Inn value, corresponding to the area that remains open; fish pond operators encroaching the Inn must in theory pay according to the share of the Inn area their ponds cover. Delineating an Inn is difficult and cases for assigning the value of the Inn to be paid by different actors are usually dealt with through local arrangements. Inn fisheries altered by fish ponds may simply be abolished by the Regional Minister of Agriculture, Livestock and Irrigation in coordination with the DoF.
} 
2016/2017, the regional government also decided to stop granting kyei"taing Inn, or long-term leases, in an attempt to break the monopoly non-residents had over Inn fisheries. The practice, however, was re-initiated in May 2018, after the remaining leases that had been granted under the previous government came to an end, in a move that may illustrate that other patronage networks are structuring themselves.
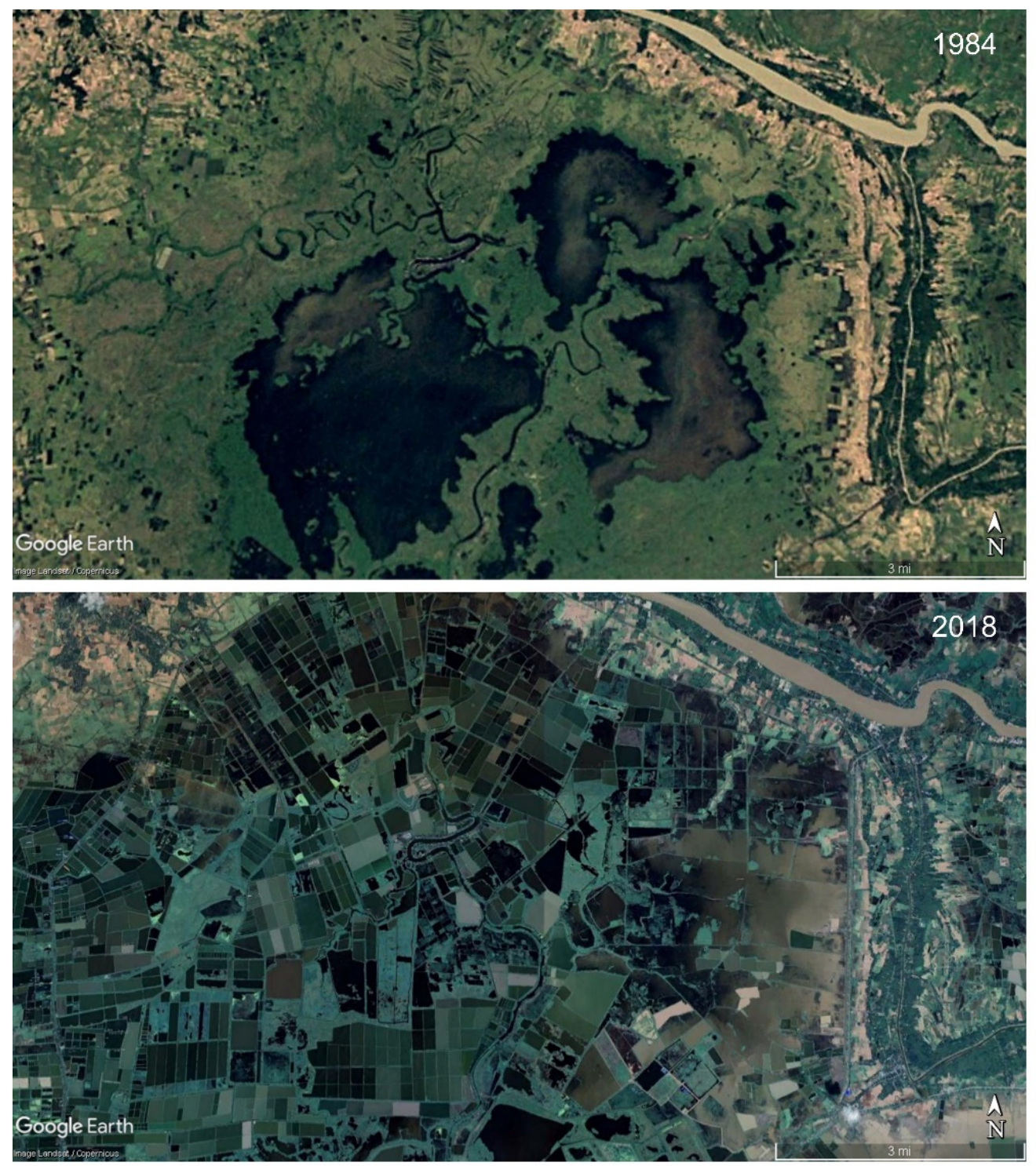

Figure 3: Landscape transformation in the case study area (1984-2018). (images: Google Earth).

The group system is controversial; rich fishermen who had privileged relations with selected officials from the Department of Fisheries (DoF) often used groups as dummies to continue securing their access to fishing grounds. Although the Directive proved successful in redirecting some Inn to village residents, it did not lead to the dismantlement of existing patronage networks. Rather, it led to their restructuring, reducing the importance that outside concessionaries had gained over the last two decades to the benefit of local village elites (often politically engaged) and fish traders. Members of Parliament have also become key cogs in these networks and there has been growing friction between them, DoF officials, the General Administration 
Department (GAD), ${ }^{14}$ and the Regional Minister of Agriculture, Livestock and Irrigation (MoALI) (Hein Ko Soe 2018) as each side indeed attempts to ensure that Inn fisheries benefit its clients, as the case below illustrates.

Let us now turn towards the Sein Company to illustrate the above dynamics. ${ }^{15}$ In the late 1990s, the company was granted an area of 465 ha of VFVL in Yeinek. The concession partly encroached two Inn fisheries (the Nga Gyi and Ngwe Aing Inn on Figure 4) which were de facto granted to the company in a closed-door auction and under a long term lease although it had no interest in their exploitation (in theory, against payment of the corresponding share of the Inn auction value). In 2003, the company received an official authorization (La Na 39 form) to turn its concession land into fish ponds. When the manager of the company initiated the construction of embankments, this triggered disputes with local fishermen who had long used the Inn fisheries under informal agreements with the company and former Inn leaseholders. Excavation, however, continued, de facto replacing the Nga Gyi Inn by fish ponds and leaving only part of the Ngwe Aing Inn area opened. After the construction of the fish ponds, the company's director sub-let part of the concession area to another entrepreneur who himself sold access to the still open water area of the Ngwe Aing Inn to local fishermen.

In 2016, a group of fishermen who had long fished in the Ngwe Aing Inn (including through sub-letting agreements with the company and after it was partly encroached on by fish ponds), used the opportunity offered by the new political context to reclaim direct access to the area. They first faced resistance from officials at the Department of Fisheries. The latter refused the fishermen's bid for the Inn on the ground that their claim would lead to "complication" as it went against the company's claim and practices. ${ }^{16}$ Acting under pressure from Members of Parliament who wanted to fulfil an electoral promise to secure and extend their support base, the District Fishery Auction Committee eventually granted the Inn to the group in 2017 (on the grounds of its low auction value and of its conflictual nature). In their new position as leaseholders, the fishermen then filed a complaint to the Township Reinvestigation Committee ${ }^{17}$ against the company. They claimed that the company was blocking access to a large part of their fishery, because of the fish ponds embankments. The Township Reinvestigation Committee conducted field investigations and concluded that, indeed, fish ponds of the company encroached about 20 ha of 'Inn land' (Inn-myei).

The Township Reinvestigation Committee further issued a letter to the company arguing that 'Inn land' was not defined as agricultural land in the 1953 Land Nationalization Act hence could not be used for aquaculture, even though the company had been granted a La Na 39 certificate for the area in the early 2000s. The company director considered the claims of the Township Reinvestigation Committee as irrelevant and sued its members, including two MPs, for trespassing as part of their field investigation. In return, the Department of Fisheries rebuked the company citing the 2012 Ayeyarwady Region Freshwater Fishery Law for trespassing on Inn territory (ne-ni-meik), even though the DoF had reportedly granted the Inn to the company in the past.

\footnotetext{
14 The General Administration Department (GAD) is under the Ministry of Home Affairs and oversees government administration. Officials of the GAD often obstruct land and fishery redistribution (e.g. Mark and Belton 2020) and continue to side with companies and powerful VTAs who previously controlled such resources. In late 2018, the Myanmar Government announced the transfer of the GAD to the civilian Ministry of the Office of the Union Government, in what constitutes another attempt at dismantling existing clientelist networks.

15 The Company is part of the Ngwe Taung Group and was created in February 1998 by a rich entrepreneur who had strong ties with the military regime. Among other activities, it is also involved in the construction and hotels business.

${ }^{16}$ The other reason why DoF officers were reluctant to recognize local fishermens' claims is that they were embedded in the patronage network of the company, deriving resources needed for their own advancement within the Ministry. Part of the complexity of local resource-making strategies relates to administrative dynamics. As told by different officials from departments under the Ministry of Agriculture, Livestock and Irrigation (MoALI), geographic mobility is a condition for climbing up the Ministry hierarchy. We were told by several officials that the Maubin District area (including the Nyaungdone Island) are not 'desirable' offices as conflicts between farmers and fishermen or between fish ponds and Inn very often set the scene. This means civil servants are subjected to heavy pressures and multiple demands that are hard to satisfy. On the other hand, such situations also provide opportunities for personal financial gain and promotion within the Ministry hierarchy if they can achieve successful conflict resolution and networking strategies.

${ }^{17}$ Also known as Reinvestigation Committee for Confiscated Farmlands and Other Lands created in 2016 by the NLD-led government (see below).
} 
According to court extracts, the company director emphasized that instructions given under the previous regime were to reclaim the open water areas in the vicinity of his concession and that the decision of the DoF to grant the Ngwe Aing Inn to a group of small-scale fishermen in 2016 was contrary to this. The company further refuted the accusation of encroachment as it considered the Inn to be de facto included into its concession area. Finally, it rejected the request made by the Township Reinvestigation Committee that the company contributes to the Inn fishery auction price (proportionally to the area it encroached, i.e. 20 ha). The company director argued that the company had bought the fish breeding license for the area (based on La Na 39) and that paying the Inn value would be tantamount to double taxation. Although the case filed by the company was dismissed in March 2018, its director still refuses to pay its share of the Inn value, and the operators who rent the fish ponds that are encroaching the Ngwe Aing Inn from the company still prevent local fishermen from accessing the area. The local fishermen who had become leaseholders are, however, documenting such wrongdoings (pik-kyek). This can be seen as a strategy to open a new resource-front: by arguing that the concession is underused (some ponds are covered with grass) or that the company and the sub-lessees do not respect the law, they entertain the idea that the concession could be cancelled -something that has been the object of rumors locally. To sum up, the new directives do not lead to an overhaul of past resource configurations; they consist of yet another lever for resource-making, further raising uncertainty over the nature of resources and the legitimacy of multiple claims and counterclaims.

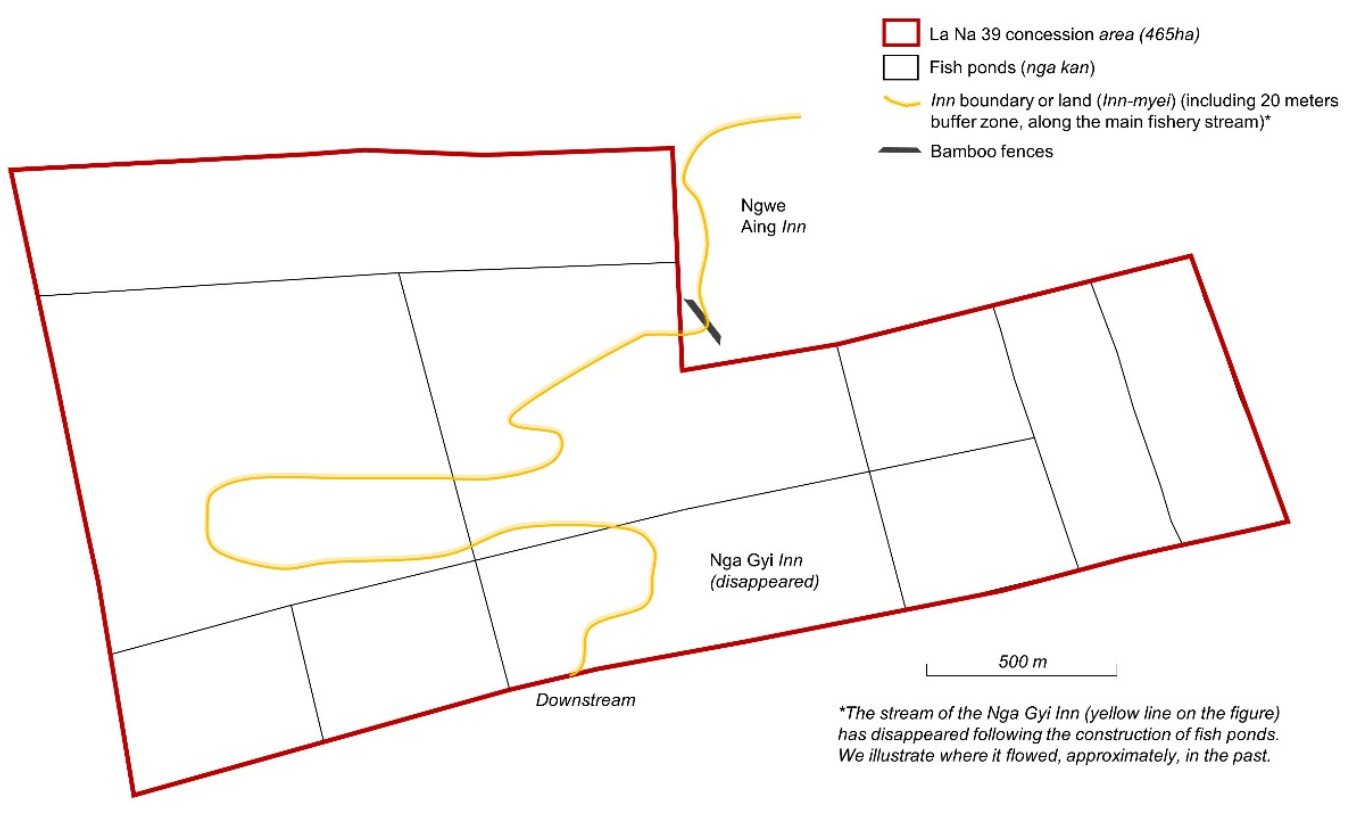

Figure 4: Schematic map of the Sein concession area as of 2018. (source: the authors)

\section{Returning the land}

In 2012, the government drafted the Farmland Law and the Vacant, Fallow and Virgin Land (VFVL) Law (Gelbort 2018; Oberndorf 2012). The same year, the Union Parliament established the Parliamentary and Investigation Commission (PLIC) to examine and solve cases farmers presented as being land grabs. In the delta, including on Nyaungdone Island, several land reallocation schemes were implemented under the Thein Sein USDP government (2011-2016) as well as under the National League for Democracy (NLD) government 
(2016- $)^{18}$ (see Figure 5). In 2016, the government created the central reinvestigation committee for confiscated lands and other lands, which replaced the PLIC, and has sub-committees at lower administrative levels.

According to a special commission from the Ayeyarwady Regional Parliament, in 2017, only 27,000 out of the 68,800 hectares of VFVL registered as leased in the Ayeyarwady Region, were used (Salai Thant Zin 2017; San Thein et al. 2018). In this context, the Ayeyarwady Region government engaged in multiple initiatives that aimed at "returning land" that had been legally leased under the 1991 Wasteland Instructions but had remained unused (Mark and Belton 2020). These initiatives are de facto remaking land resources for delta inhabitants. Two types of land re-allocation can be distinguished: (1) state-led large-scale re-allocation schemes of unused concession land ${ }^{19}$ and (2) small-scale re-allocation of land based on direct claims filed by individuals or groups resorting to the 2012 VFVL Law (amended in 2018). In both cases, information and knowledge over the availability and status of land is crucial and Village Tract Administrators, clerks and rural elites who are the depository of such information have used it to their own benefit, making them the primary - though not the only- beneficiaries of these recent land re-allocation dynamics.

If we turn again to Yeinek, 4,050 ha initially granted to the Treasure Land Company (TLC) in the area were withdrawn and redistributed by the central authorities in 2000/2001 on the grounds that it had not been reclaimed. At the time, the beneficiaries of the redistribution included various government departments, individual entrepreneurs and entities including a Myanmar Army (Tatmadaw) related organization (162 ha) and the Shwe Nadi Company (1070 ha). In 2013, part of this land was further identified as not having been used for the last four years, and the related concessions annulled for re-allocation by the new USDP-led regional government. In this section, we focus on two cases which illustrate the current dynamics of land reallocation across Nyaungdone Island.

The area granted in 2000/2001 to the Myanmar Army related organization (162 ha) had received a La Na 39 form. In 2015, it was redistributed to a former army staff-member who had close relationships with the former Village Tract Administrator (who occupied the position between 1999 and 2017), as the daughter of the former had married the latter's son. Before the re-allocation, local fishermen fished in the area. When the grant of land was made official in 2015, the former VTA (who managed the area for the army staff-member who had benefited from the redistribution) initiated the construction of embankments to turn the flooded area into fish ponds. This created tensions with a group of capture fishermen from two villages of Yeinek who claimed they had requested access to the area since 2014. The claimants argued that they had traditionally used the area as a fishery site and that it originally belonged to residents of their villages and not to the village of the former VTA, thus highlighting that disputes can be very local in nature. ${ }^{20}$ They complained to the regional level MoALI that the allocation of 162 ha of VFVL was contrary to the 2012 VFVL Law, section 10 (a) that states that an individual can only receive a maximum of 4 hectares of land the first year and 20 ha in total (and that only if $75 \%$ of the initial grant area was successfully developed). Despite warning from the Regional MoALI office, fish pond excavation continued. Some of our interlocutors are still hoping that this allocation, which they interpret as grabbing, could be cancelled and the area redistributed, this time to them. Considering this area to be an Inn surrounded by embankments, as opposed to being made of fish ponds, they also argue that the area should be allocated as a fishery site, in what illustrates a dispute concerning the nature of the resource to be allocated itself (as also shown in Section 4).

\footnotetext{
${ }^{18}$ According to two field reports shared by the French NGO GRET that carried out studies on land reallocation schemes across the country including in the delta.

${ }^{19}$ In and around Yeinek, two such re-allocations took place since 2012. They concerned land earlier allocated to the Shwe Nadi Company (403 ha) and the ABC Company (782 ha).

${ }^{20}$ The residents of the four main villages under Yeinek are divided in two main groups. The scission originated from a political rivalry around the selection of a new monk in the then only monastery of the area in the 1960-1970s. Local fishermen mention these tensions during our interviews to stress that they considered the former VTA and his 'followers' as outsiders to the area they claimed. These tensions do not prevent social and economic exchanges between residents across the different villages.
} 


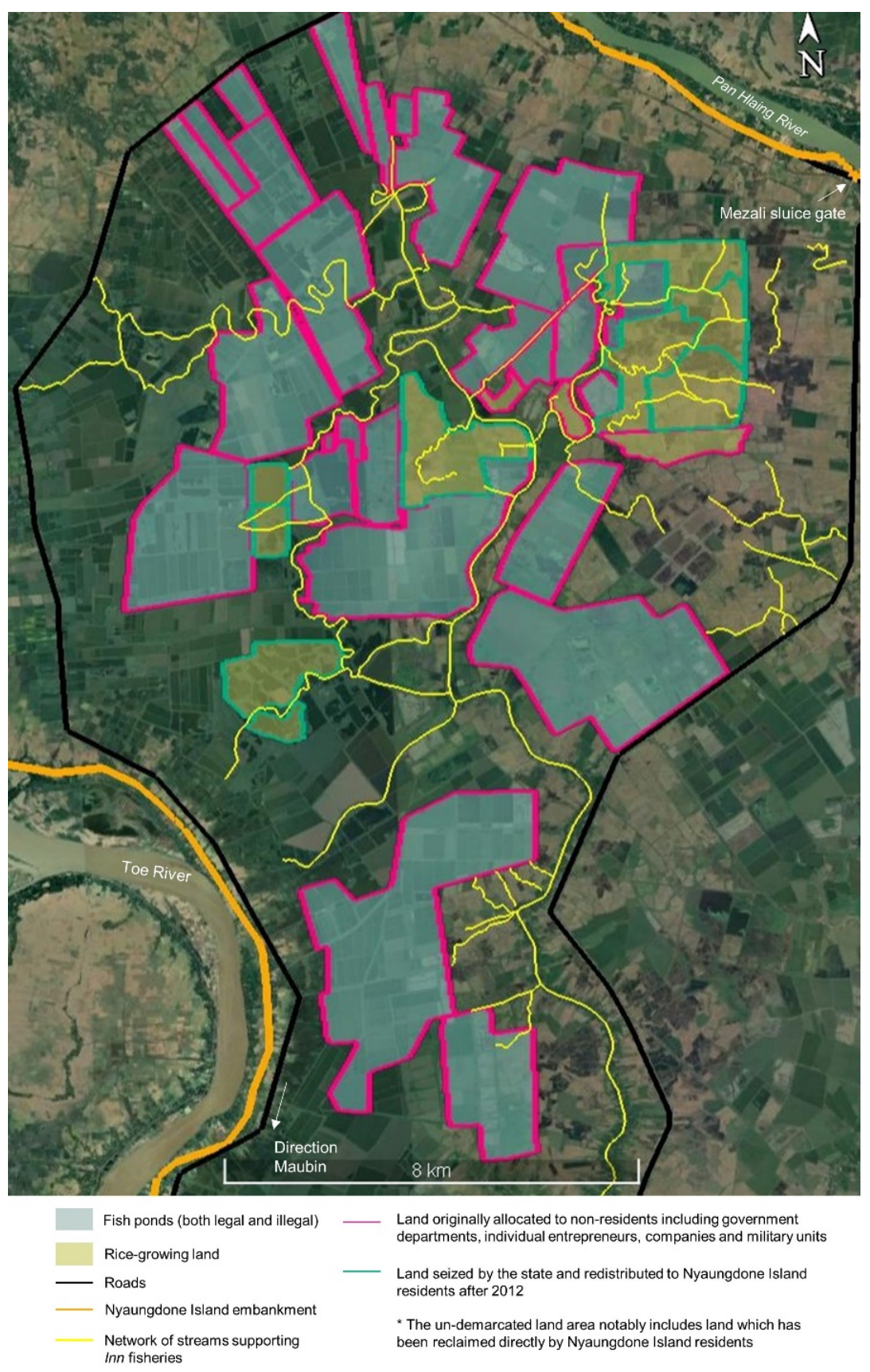

Figure 5: Illustrative rather than exhaustive map of the fragmented resource landscape in Nyaungdone Island (source: the authors based on official records and fieldwork conducted in 2019; image: Google Earth as of 2019).

Another example of resource-making is provided by the reallocation scheme that targeted land formally allocated to the Shwe Nadi Company. The reallocation scheme was initiated in 2015, a national election year. The Shwe Nadi Company had been established in 2001 and is a Tatmadaw (Myanmar army) owned company. In 2001, it received a total of 1,070 hectares of VFVL (part of which had been earlier allocated to TLC) and, 
over the following years, it was granted $\mathrm{La} \mathrm{Na} 39$ forms for 790 hectares out of the total concession area. In 2013, the company had converted 607 hectares of land into fish ponds. According to district authorities, out of these, 593 ha had $\mathrm{La} \mathrm{Na} 39$ form and 81 ha did not (the company had a pending application for La Na 39 forms for the remaining 280 ha of its concession area). The remaining 198 ha served as capture fishery grounds.

In 2013, making use of the 2012 VFVL law provisions, a group of residents of Yeinek laid claim to what they saw as being an unused area. In 2015, and following residents' requests, the regional government instructed the re-allocation of 395 hectares of land that it considered unused (e.g. the area not converted into fish ponds but in practice used for capture fisheries by local fishermen who negotiated access from the company through the payment of an entry fee). On the ground, 332 hectares were finally distributed to landless farmers from neighboring villages. ${ }^{21}$

Residents of Yeinek received a total of 146 ha, at between 0.40 or 0.80 ha per household depending on the number of eligible households at village level. The list of eligible households was prepared by the VTA and included a mix of landless households (capture fishermen who were considered as being the "original" users) and "squatter" households who claimed to have cultivated land in the area in the past. As of today, land in the redistributed area can be cultivated with summer rice during the dry season and is flooded the rest of the year, which highlights the hybridity of resources co-existing in the same spatial area. Land redistribution led to significant reorganization of landholdings, as many beneficiaries sold the plots they had been granted to other villagers. The main reason advanced by our interlocutors was that the amount of land they received was insufficient, and many used it to repay existing debts. Although the reallocation enabled the constitution of a new resource, i.e. farmland for rice cultivation, it appears that the processes of capital accumulation and indebtedness are key to shaping resource reconfigurations. Moreover, beneficiaries of the re-allocation scheme have achieved different levels of land tenure security. Some have been able to obtain land use certificates that serve as land titles while others have not yet fully secured their claims and are worried that their land could be seized by the state (on the process of land tenure security and registration, see Boutry et al. 2017). Finally, some farmers who purchased land started to convert their land into fish ponds, without official permission. Uncertainties hence remain...

\section{Conclusion}

This article shows that, until recently, successive political regimes have enacted the Ayeyarwady Delta as a frontier in a classic understanding of the term, that is, a vast empty space to be conquered. As broadly argued by Fold and Hirsh (2009: 95) about "the frontier" in South East Asia, enacting the Ayeyarwady Delta as a frontier in that particular way made it a symbol of national development; it also hinged on the "making of land" as a valuable yet underutilized resource that needed to be tapped into.

The state's attempts at shaping resources dynamics in the delta mostly consisted of large-scale land allocation and infrastructure development schemes (Ivars and Venot 2019). The case study highlights that such attempts involved state-led violence, something that Watts (2018) stresses characterizes frontier-making, and led to large-scale dispossession and marginalization of small-scale farmers and fishermen (see also Hall et al. 2011; Lund 2018). We show that under the SLORC/SPDC regimes, natural resources were reconfigured through cross-scale economic patronage networks involving army staff, national entrepreneurs and local government officials, with village elites playing a key brokerage role in these networks.

But, grounded in recent political ecology scholarship, ethnographic work in Yeinek village tract allows us to go beyond this image of the delta as a somehow inert land/rice-frontier and beyond the classic

\footnotetext{
21 There are several possibilities as to what happened to the remaining 63 hectares: (1) 24 hectares near the redistributed area had been cleared by villagers prior to the official reallocation and they may have maintained their right to cultivate the land though without official recognition; (2) the 162 hectares of land that are disputed and that we described above are adjacent to the Shwe Nadi Company concession and it may well be that some of the land considered as unused by the district authority in the present adjudication case actually belong to the concession and have not been allocated; (3) finally, some land might have been 'set aside' for future village development activities (school, hospital, monastery) and/or be appropriated by local elites.
} 
understanding of the concepts of 'resources' and 'frontier' themselves. For once, what first strikes the visitor to Yeinek is the omnipresence of water and fish ponds. In a deltaic environment, land and water resources are hardly mutually exclusive as land put under cultivation during one season can then be flooded and serve as a productive fishing ground the next season. This calls for shifting attention from resources as a 'given', towards resource-making strategies and their politics. As for the frontier, resources are enacted, socially and politically. Our case study clearly shows that, in Nyaungdone Island, the making of land as the potential resource and of rice cultivation as the political horizon is what underpinned the classification of vast areas as being "unused", "vacant" or "underutilized." This not only made their allocation to well-connected local elites and outsiders possible and legitimate but, in the process, undermined capture fishermen's claims by pushing them in the shadows.

Second, an understanding of resources and frontiers grounded in relational and assemblage analytics (e.g. Barney, 2009; Cons and Eilenberg, 2019) leads us to conceptualize the institutional dynamics triggered by the recent transition to civilian governments as resources and frontiers in themselves. As new (land and fishery) legal frameworks have been enacted, new resources-making strategies and related claims whether focused on land, Inn fisheries, or fish ponds (or any combination of those) are made by state or non-state actors. These encounter each other. Far from replacing past resource making strategies, claims and legitimacy frameworks (the early $20^{\text {th }}$ century maps are still, for instance, the only legal documents on the basis of which capture fishery areas are officially delineated), the new laws and claims "pile up" as to form an ever more complex millefeuille (multiple layers) that are challenging to navigate, can trigger conflicts but also open up new horizons and possibilities (see also Boutry et al. 2017; Hong 2017; Mark 2016; Scurrah et al. 2015; Suhardiman et al. 2019a, 2019b for a description of Myanmar land sector institutional pluralism).

What our case study shows is that local inhabitants navigate this frontier in heterogeneous ways. The new land laws and directives offer new opportunities to voice claims and prompt a redistribution of the delta's resources. However, these redistribution processes meant to correct the effects of past state interventions and large-scale dispossession are highly politicized. Whether the focus on land that still underpins the most recent reforms will allow redressing past and current inequalities remains to be seen, given the hybrid character of the delta and the importance of fisheries (Mark and Belton 2020; Radford and Lamb 2020). Further, contemporary struggles incorporate and perpetuate the past history of resource-making and cross-scale patronage networks, and continue to determine who benefits from the remaking of delta resources. In this context, village elites who have preferential access to information and knowledge about the resources intended for re-distribution and connections to authorities at different levels of the government apparatus continue to benefit from current reconfigurations, while vulnerable people remain on the margins. As has historically been the case in the Ayeyarwady Delta (Adas 1974; van Schendel 1991), interrelationships of capital accumulation and indebtedness largely determine who derives benefits from newly (re)made resources such as fish ponds or Inn fisheries.

To sum up, multiple frontiers are at play in village tracts such as Yeinek and more generally across areas such as Nyaungdone Island that have not been fully converted to rice growing through past land reclamation projects (contrary to the west of the delta and the polders funded by the World Bank in the 1970s and 1980s). The centers of these islands are still the targets of state and non-state attempts to reconfigure access to and control over resources, in as much that they can still be seen as frontiers in the classic sense of the term. But resource-making in these areas takes place in a context of uncertainty due to multiple encounters between former, current and potential resource uses and users, the enactment of new legal regimes and directives that do not fully replace older ones but "just pile up", or the reconfigurations of clientelist networks. Such uncertainty is not only a resultant feature of complex social, political and economic forces but is actually "made" and constitutes a frontier in itself. It emerges as a 'space' that is "neither clearly and coherently within nor outside the logics of territorial rules" (Cons and Eilenberg 2019: 16) but "in-between" and constituting another frontier to conquer. Resource and frontier-making remain, then, a persistent feature of the Ayeyarwady Delta. 


\section{References}

Adas, M. 1974. The Burma Delta: economic development and social change on an Asian rice frontier, 18521941. Madison, WI: University of Wisconsin Press.

Aung Zaw. 2008. Operation Delta. The Irrawaddy, June 2008 [accessed November 18 ${ }^{\text {th }}$, 2019].

Bakker, K. and G. Bridge. 2006. Material worlds? Resource geographies and the 'matter of nature'. Progress in Human Geography 30(1): 1-23.

Barnett, C.G. 1913. Note on protective embankment in the Delta 1862-1912. Rangoon, Burma: Office of the superintendent, Government printing.

Barney, K. 2009. Laos and the making of a 'relational' resource frontier. The Geographical Journal 175(2): 146-159.

Belton, B., A. Hein, K. Htoo, L.S. Kham, U. Nischan, T. Reardon and D. Boughton. 2015. Aquaculture in transition: value chain transformation, fish and food security in Myanmar. International Development Working Paper 139. East Lansing, MI: Michigan State University.

Biggs, D. 2011. Quagmire: nation-building and nature in the Mekong Delta. Seattle, WA: University of Washington Press.

Boutry, M., C. Allaverdian, M. Mellac, S. Huard, San Thein, Tin Myo Win and Khin Pyae Sone. 2017. Land tenure in rural lowland Myanmar: from historical perspectives to contemporary realities in the Dry Zone and the Delta. Yangon, Myanmar: GRET Research Report, Of Lives of Land Myanmar Research Series.

Bridge, G. 2009. Material worlds: natural resources, resource geography and the material economy. Geography Compass 3(3): 1217-1244.

Campbell, S. 2019. Reading Myanmar's inland fisheries: postcolonial literature as theoretical lens. Inter-Asia Cultural Studies 20(1): 2-18.

Cons, J. and M. Eilenberg. 2019. Frontier assemblages: the emergent politics of resource frontiers in Asia. London: Wiley.

England, F.S.E. 1939. Report on flood conditions and levels in the Irrawaddy Delta. Rangoon, Burma: Government Printing.

Ferguson, J.M. 2014. The scramble for the waste lands: tracking colonial legacies, counterinsurgency and international investment through the lens of land laws in Burma/Myanmar. Singapore Journal of Tropical Geography 35(3): 295-311.

Filipski, M. and B. Belton. 2018. Give a man a fishpond: modeling the impacts of aquaculture in the rural economy. World Development 110: 205-223.

Fold, N. and P. Hirsch. 2009. Re-thinking frontiers in Southeast Asia. Geographical Journal 175(2): 95-97.

Gelbort, J. 2018. Implementation of Burma's Vacant, Fallow and Virgin Land Management Law: at odds with the nationwide ceasefire agreement and peace negotiations. Amsterdam: Transnational Institute (TNI).

Government of British Burma (GoBB). 1923. Collection of reports of the Yandoon Island Colonisation Scheme in the Maubin District during the years 1912 to 1922. Rangoon, Burma: Office of the Superintendent, Government Printing.

Hall, D., P. Hirsch and T.M. Li. 2011. Powers of exclusion: land dilemmas in Southeast Asia. Singapore and Honolulu: National University of Singapore Press/University of Hawaii Press.

Hein Ko Soe. 2018. Fishy business in Ayeyarwady as industry reforms scuppered. Frontier Myanmar, 19 February 2018 [accessed May 05 ${ }^{\text {th }}$ 2019].

Hong, E. 2017. Scaling struggles over land and law: autonomy, investment and interlegality in Myanmar's borderlands. Geoforum 82: 225-236.

Htwe Myint, U. 1990. Nyaungdone Polder Rehabilitation Project feasibility report. Irrigation Department. Ministry of Agriculture and Irrigation. Government of Myanmar. (in Burmese) 
Hudson-Rodd, N. and Sein Htay. 2008. Arbitrary confiscation of farmers' land by the state peace and development council military regime in Burma. Rockville, MD: The Burma Fund.

Information Department. 1962. The Burmese way to socialism (No. 48), Towards socialism in our Burmese way. Rangoon, Burma: Ministry of Information, Government of Burma.

Irrigation Department. 1988. Land survey report on Nyaungdone Island reclamation project. Paddyland II. Rangoon, Burma: Government of Burma. (in Burmese)

Ivars, B. and J-P Venot. 2019. Grounded and global: water infrastructures development and policy in the Ayeyarwady Delta, Myanmar. Water Alternatives 19(3): 1038-1063.

Khin, U. 1948. Fisheries in Burma. Rangoon, Burma: Office of the Superintendent, Government Printing.

Kopytoff, I. 1987. The internal African frontier: the making of African political culture. In Kopytoff I. (ed.). The African frontier: the reproduction of traditional African societies. Bloomington-Indianapolis, Indiana: University Press.

Li, T.M. 2014a. What is land? Assembling a resource for global investment. Transactions of the Institute of British Geographers 39(4): 589-602.

Li, T.M. 2014b. Land's end: capitalist relations on an indigenous frontier. Durham, NC: Duke University Press.

Lund, C. 2018. Predatory peace: dispossession at Aceh's oil palm frontier. Journal of Peasant Studies 45(2): 667-681.

Mark, S. 2016. Are the odds of justice 'stacked' against them? Challenges and opportunities for securing land claims by smallholder farmers in Myanmar. Critical Asian Studies 48(3): 443-460.

Mark, S. 2017. Fish farms and land confiscation in the Ayeyarwady Delta: history, impact and prospects for restitution. Feed the Future Innovation Lab for Food Security Policy Research Brief 44. East Lansing, MI: Michigan State University.

Mark, S. and B. Belton. 2020. Breaking with the past? Land restitution and the limits to restitutive justice in Myanmar. Land Use Policy 94.

Maung Aung Myoe. 1999. The counterinsurgency in Myanmar: the government's response to the Burma Communist Party. PhD Dissertation. Canberra: Australian National University.

Maxwell, 1910. A fishery handbook. Rangoon, Burma: Office of the Superintendent, Government Printing.

Ministry of Agriculture and Irrigation (MoAI). 2002. Nyaungdone Island Land Reclamation Project Ayeyarwady Division. Irrigation Department. Ministry of Agriculture \& Irrigation. The Government of Myanmar.

Oberndorf, R. 2012. Legal review of recently enacted farmland law and vacant, fallow and virgin lands management law. Yangon, Myanmar: Land Core Group (LCG).

Peluso, N.L. 2012. What's nature got to do with it? A situated historical perspective on socio-natural commodities. Development and Change 43(1): 70-104.

Peluso, N.L. 2018. Entangled territories in small-scale gold mining frontiers: Labor practices, property, and secrets in Indonesian gold country. World Development 101: 400-416.

Peluso, N.L. and C. Lund. 2011. New frontiers of land control: introduction. Journal of Peasant Studies 38: 667-681.

Peluso, N.L. and P. Vandergeest. 2011. Political ecologies of war and forests: counterinsurgencies and the making of national natures. Annals of the Association of American Geographers 101(3): 587-608.

Public Works Department (PWD). 1927. Report of the Floods Enquiry Committee 1924-1925. Rangoon, Burma: Office of the Superintendent, Government Printing and Stationery.

Radford, S. and V. Lamb. 2020. Work and struggle of fishing livelihoods in the Delta: development and 'new' change along the Ayeyarwady (Irrawaddy) River, Myanmar. Asia Pacific Viewpoint https://doi.org/10.1111/apv.12256

Rasmussen, M.B. and C. Lund. 2018. Reconfiguring frontier spaces: the territorialisation of resource control. World Development 101: 388-399. 
Reeves, P., B. Pokrant and J. McGuire. 1999. The auction lease system in Lower Burma's fisheries, 1870-1904: implications for artisanal fishers and lessees. Journal of Southeast Asian Studies 30(2): 249-262.

Ribot, J.C. and N.L. Peluso. 2003. A theory of access. Rural Sociology 68(2): 153-181.

Richardson, T. and G. Weszkalnys. 2014. Introduction: resource materialities. Anthropological Quarterly 87(1): 5-30.

Salai Thant Zin. 2017. Companies rush to use inactive lands after govt announces seizure. The Irrawaddy, 25 July 2017 [accessed June $26^{\text {th }}$, 2019].

Salai Thant Zin. 2019a. Irrawaddy Region farmers' hopes of reclaiming stolen land running thin. The Irrawaddy, 25 March 2019 [accessed March 29 $9^{\text {th }}$ 2019].

Salai Thant Zin. 2019b. Court acquits 8 farmers sued by owner of unused land in Irrawaddy Region. The Irrawaddy, 7 January 2019 [accessed March $8^{\text {th }}, 2019$ ].

San Thein., J-C. Diepart, Hlwan Moe and C. Allaverdian. 2018. Large-scale land acquisitions for agricultural development in Myanmar: a review of past and current processes. Vientiane, Laos: Mekong Region Land Governance (MRLG).

San Thein., Khin Pyae Sone and J-C. Diepart. 2017. Transparency under scrutiny. information disclosure by the Parliamentary Land Investigation Commission in Myanmar. Vientiane, Laos: Mekong Region Land Governance (MRLG).

Scurrah, N., P. Hirsch and K. Woods. 2015. The political economy of land governance in Myanmar. Vientiane, Laos: Mekong Region Land Governance (MRLG).

Sir William Halcrow \& Partners. 1982. Irrawaddy Delta hydrological investigations and delta survey. 5 volumes. Washington, DC: World Bank.

Smeaton, D.M. 1882. Note on inland fisheries by the Director of Agriculture, British Burma dated 17 July 1882. Government Printing.

Smith, M. 1999. Burma: insurgency and the politics of ethnic conflict. Second edition. London: Zed.

South, A. and M. Katsabanis. 2007. Displacement and dispossession: forced migration and land rights in Burma. Geneva: Centre on Housing Rights and Evictions (COHRE).

Suhardiman, D., M. Kenney-Lazar, and R. Meinzen-Dick. 2019a. The contested terrain of land governance reform in Myanmar. Critical Asian Studies 51(3): 368-385.

Suhardiman, D., J. Bright and C. Palmano. 2019b. The politics of legal pluralism in the shaping of spatial power in Myanmar's land governance. The Journal of Peasant Studies. https://doi.org/10.1080/03066150.2019.1656200

Tezzo X., Y. Kura, E. Baran and Ziza Wah. 2016. Individual tenure and commercial management of Myanmar's inland fish resources. In Song A., S. Bower, S. Cooke, P. Onyango and R. Chuenpagdee. (eds). Intersectoral governance of inland fisheries: too big to ignore. St John's, NL: Global Partnership for SmallScale Fisheries Research (TBTI).

Tezzo, X., B. Belton, G. Johnstone and M. Callow. 2018. Myanmar's fisheries in transition: current status and opportunities for policy reform. Marine Policy 97: 91-100.

Thawnghmung, A.M. 2003. The socio-economic impacts of rice policies implementation in rural Burma/Myanmar. Sojourn 18(2): 299-321.

Thawnghmung, A.M. 2004. Behind the teak curtain: authoritarianism, agricultural policies, and political legitimacy in rural Burma/Myanmar. London: Kegan Paul.

The New Light of Myanmar. 2003b. Ayeyarwady Division rapidly developing, due to prevalence of peace and stability and smooth transport. 1 August 2003. [accessed July 15 ${ }^{\text {th }}$, 2019].

The New Light of Myanmar. 2003a. Lt-Gen Thura Shwe Mann, Secretary-2 Lt-Gen Soe Win meet with agriculture \& livestock breeding entrepreneurs in Ayeyarwady Division. 6 July 2003 [accessed November $12^{\text {th }}$, 2019]. 
The New Light of Myanmar. National entrepreneurs urged to do large-scale farming and build agro-based industries and take lead in market economy in future. 27 January 1999 [accessed November 14 ${ }^{\text {th }}, 2019$ ].

The New Light of Myanmar. 2001. Secretary-3 inspects preparations for prawn breeding, poultry farming and fish breeding. 26 March 2001 [accessed November 17th 2019 ].

Tin Gyi, U. 1927. Note on the conflict of interests between cultivation and fisheries in the Maubin and Pyapon Districts of Lower Burma. Government Printing.

Tsing, A.L. 2011. Friction: an ethnography of global connection. Princeton: Princeton University Press.

Turner, F.J. 1920. The frontier in American history. New York: Henry Holt.

van Schendel, W. 1991. Three deltas: accumulation and poverty in rural Burma, Bengal and South India. IndoDutch Studies on Development Alternatives No. 8. New Delhi, India: SAGE.

Volker, A. 1964. Surface hydrology of deltaic areas. In Proceedings of the Dacca Symposium on scientific problems of the humid tropical zone deltas and their implications. University of Dacca, Bangladesh: UNESCO Publications.

Warr, P.C. 2000. The failure of Myanmar's agricultural policies. Southeast Asian Affairs. ISEAS, Singapore: 219-238.

Watts, M.J. 2012. A tale of two gulfs: life, death, and dispossession along two oil frontiers. American Quarterly 64: 437-467.

Watts, M.J. 2018. Frontiers: authority, precarity, and insurgency at the edge of the state. World Development 101: 477-488.

Woods, K. 2011. Ceasefire capitalism: military-private partnerships, resource concessions and military-state building in the Burma-China borderlands. Journal of Peasant Studies 38(4): 747-770.

World Bank. 1976. Lower Burma Paddyland Development Project. Appraisal report. Washington, DC: World Bank.

World Bank. 1978. Paddyland Development II Project. Staff appraisal report. Washington, DC: World Bank.

Yin Nyein, B., R.G. Gregory and Aung Kyaw Thein. 2018. Confusion, uncertainty. Myanmar fisheries governance. Samudra Report No. 80: 28-30. 